| Clinical | Trial |

\title{
Effects of solasodine of Solanum melongena peel origin in the treatment
}

\section{of palmar arsenical keratosis}

\author{
Razia Sultana and Mir Misbahuddin
}

\begin{tabular}{|c|c|}
\hline \multicolumn{2}{|l|}{ Article Info } \\
\hline \multicolumn{2}{|c|}{$\begin{array}{l}\text { Division of Arsenic Basic Research, } \\
\text { Department of Pharmacology, Faculty of } \\
\text { Basic Science and Paraclinical Science, } \\
\text { Bangabandhu Sheikh Mujib Medical } \\
\text { University, Shahbag, Dhaka, Bangladesh }\end{array}$} \\
\hline \multicolumn{2}{|c|}{$\begin{array}{l}\text { For Correspondence: } \\
\text { Mir Misbahuddin } \\
\text { mmisbah@bsmmu.edu.bd }\end{array}$} \\
\hline Received: & 8 January 2020 \\
\hline Accepted: & 26 May 2020 \\
\hline Available Online: & 16 June 2020 \\
\hline
\end{tabular}

ISSN: 2224-7750 (Online) 2074-2908 (Print)

DOI: $10.3329 /$ bsmmuj.v13i2.47606

Cite this article:

Sultana R, Misbahuddin M. Effects of solasodine of Solanum melongena peel origin in the treatment of palmar arsenical keratosis. Bangabandhu Sheikh Mujib Med Univ J. 2020; 13: 47-52.

Copyright:

The copyright of this article is retained by the author(s) [Atribution CC-By 4.0]

\section{Available at:}

www.banglajol.info

A Journal of Bangabandhu Sheikh Mujib Medical University, Dhaka, Bangladesh
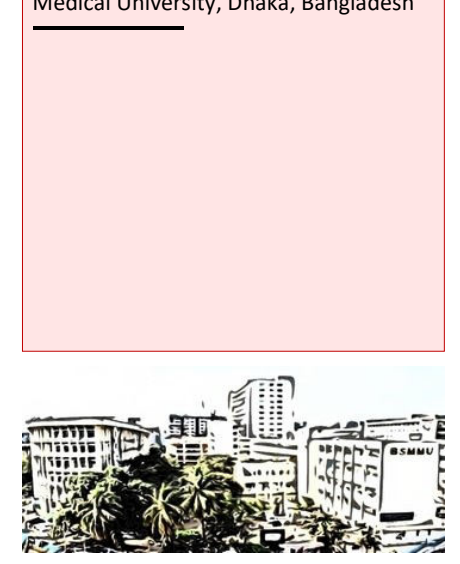

\section{Abstract}

This study was conducted to confirm the effect of the ointment containing Solanum melongena peel extract in the treatment of palmar arsenical keratosis and to identify the compound responsible for the effect. In total, 30 patients with moderate to severe palmar arsenical keratosis were enrolled according to the inclusion criteria. Extract from S. melongena peel was obtained and a topical ointment was prepared from the extract and supplied at the field level at an interval of two weeks. Instruction was given to the patients about how to apply the ointment. Adherence and adverse effects of the treatment were monitored regularly through phone calls and during each visit. The mean $\left( \pm \mathrm{SD}\right.$ ) size of the keratotic nodules was $21.9 \pm 10.0 \mathrm{~mm}^{2}$ before intervention and $6.6 \pm 5.3$ $\mathrm{mm}^{2}$ after intervention. The percentage of reduction was 69.8. Nuclear magnetic resonance spectroscopy, infrared spectroscopy, liquid chromatography-mass spectrometry and elemental analysis of the extract was done to identify the compound and solasodine, a steroidal alkaloid, was identified.

\section{Introduction}

About millions of Bangladeshi people are chronically exposed to high concentration of arsenic through contaminated drinking water and thus suffering from arsenic-related health hazards. The most common manifestation of arsenicosis is the development of keratosis in the palms and soles which affect the economic condition of the patients by reducing their working ability. It can also create social problems and possesses a negative impact on patient's mental health.1 Because of illiteracy and lack of information, people living in the rural areas consider keratosis as a contagious disease. They tend to avoid direct contact with the affected person. The presence of keratosis in the palms of unmarried girls is of great concern for their parents.?

Different types of oral antioxidants and topical preparations are applied to reduce the size of keratosis but there are several disadvantages of these therapies such as prolong duration of treatment, which in turn reduces the patient compliance or adherence to therapy, as well as produce some adverse effects and also increase treatment cost. However, stoppage of the therapy causes recurrence of keratosis.

A study conducted in the same laboratory showed that $S$. melongena peel extract was effective on arsenical keratosis. -3 Extraction of $S$. melongena peel is difficult, expensive and time- consuming. Preparation of topical medication from this natural source in a large scale is difficult and non-economic. If it is possible to identify the effective compound of S. melongena peel extract, chemical synthesis of that compound can be done and preparation of a cheaper and easily available topical medicine from that compound will be possible.

So, this study was conducted to confirm the effect of ointment containing S. melongena peel extract on arsenical keratosis as well as to identify the compound of the extract responsible to cure the disease.

\section{Materials and Methods}

The study was conducted in two arsenic affected endemic areas [Bhanga Upazilla of Faridpur District (about $150 \mathrm{~km}$ from Dhaka) and Babutipara Union, Muradnagar Upazilla, Cumilla District (about 108 km from Dhaka)] from September 2017 to January 2019.

The study was conducted on 30 patients (male 13, female 17) of moderate to severe arsenical keratosis. The inclusion criteria were a) age more than 18 years; b) consumption of arseniccontaminated water $(>50 \mu \mathrm{g} / \mathrm{L})$ for more than six months; c) moderate to severe keratosis; and d) voluntarily agreed to participate in this study. The exclusion criteria were a) expectant 
or nursing mother; b) patient who received any treatment of arsenicosis within the last three months and d) patient with any diagnosed skin diseases like atopic dermatitis, eczema, and psoriasis.

All the patients were demonstrated how to apply the ointment containing extract at the lesion site The clinical examination of patient and distribution of ointment containing $S$. melongena peel extract were done at 2 weeks interval.

Detailed history, clinical examination, and photographs of the lesions were collected. The size of the lesions was measured before and after completion of the study.

Drinking water and nail samples were collected for estimation of arsenic. One labeled polyethylene container (capacity $100 \mathrm{~mL}$ ) containing 1 drop of nitric acid was supplied to each patient in order to collect the water sample. All the collected samples were then transported to the Department of Pharmacology, Bangabandhu Sheikh Mujib Medical University and stored until analysis.

A labeled, sterile, air-tight, polyethylene bag was supplied to each patient and advised to collect finger and toe nails (growth of one month). About 200-500 mg nail samples of each patient were collected and transported to the laboratory and stored in the refrigerator until analysis. $\underline{4}$

The amount of arsenic in water and nails was measured by modified silver diethyldithiocarbamate (SDDC) method. $\underline{5}$

Specific species of $S$. melongena $L$ was identified by Bangladesh National Herbarium. Then S. melongena was collected from the local market. The average length of S. melongena were six to eight inches, circumference were three to four inches and weight was ranged from $200-300 \mathrm{~g}$.

S. melongena was rinsed thoroughly with water and dried off. Peels were removed with a peeler and cut into small pieces. Peels were then air dried at room temperature avoiding direct sunlight for two days. Dried peels were immersed into an amber color bottle containing one liter of the mixture of ethanol: chloroform: acetic acid (65: 32: 3) and kept for 72 hours at room temperature. After 72 hours, the peels and solvent were filtered through a filter paper. Filtered liquid was concentrated using a rotary evaporator at $40-50^{\circ} \mathrm{C}$ temperature. .3

\section{Brine shrimp lethality study}

About three gram of brine shrimp (Artemia salina) eggs collected from the local market were poured into a glass tank (capacity $=6 \mathrm{~L}$ ) containing artificial seawater (about $4 \mathrm{~L}$ ) for hatching up to 48 hours with continuous aeration by air flow machine and artificial light using 60 watt bulb. $\frac{6,7}{}$ One milligram extract of $S$. melongena peel was weighted by the electronic balance and dissolved in $1 \mathrm{~mL}$ of water to prepare the stock solution. Serial dilution of the stock solution was done and taken in four sterile, labeled test tubes. The concentration of the solutions after serial dilution was 100, 10, 1 and $0.1 \mu \mathrm{g} / \mathrm{mL}$.

The brine shrimp larvae (nauplii) were collected with a Pasteur pipette from the hatching chamber in the test tubes. Different concentrations of the extract were poured into the test tubes containing ten nauplii and kept in room temperature. Motility of the nauplii was observed after 2 and 24 hours.

Percentage of death $=$ [Number of dead nauplii/ (Number of dead nauplii + Number of live nauplii)] $\times 100$.

The ointment $(100 \mathrm{~g})$ contained $30 \mathrm{mg}$ of $S$. melongena peel extract, $3.97 \mathrm{~g}$ stearyl alcohol, $10 \mathrm{~g}$ white wax and $86 \mathrm{~g}$ white petrolatum. 8 White petrolatum, bee wax and stearyl alcohol were measured by an electronic balance after calibration and taken in a glass beaker. The glass beaker was placed into the bowl containing water and heated up to complete melting of the ingredients using Bunsen burner. After complete melting of the ingredients, the burner was put off and the beaker was placed in a tray for cool down. After reaching at room temperature, $S$. melongena peel extract was added and stirred well. Ointment was poured into the high-density polyethylene container and stored in a cool and dry place until supplying to the patient.

The ointment was distributed and each patient was demonstrated separately how to apply the ointment at the lesion site. Patients were instructed to apply the ointment twice daily in the morning and bedtime for 13 weeks. An adherence sheet was provided to each patient and advised to put a tick mark at the appropriate place after applying the ointment.

The keratotic lesion was monitored. Any improvement was documented and check the adherence in every follow-up visit at two weeks interval.

Paired t-test was performed manually to measure the differences between the keratotic nodular size changes before and after treatment.

\section{Steps of identification}

Compound was identified by nuclear magnetic resonance spectroscopy, Fourier-transform infrared spectrophotometry, elemental analysis and liquid chromatography-mass (LC-MS/MS) spectroscopy.

\section{Results}

The mean $( \pm$ SD) age of the patients was $41.3 \pm 13$ years. The mean amount of arsenic was $244.1 \pm$ $177.5 \mu \mathrm{g} / \mathrm{L}$ and $8.2 \pm 7.4 \mu \mathrm{g} / \mathrm{g}$ in the tube well water consumed by the patients and nail sample respec- 


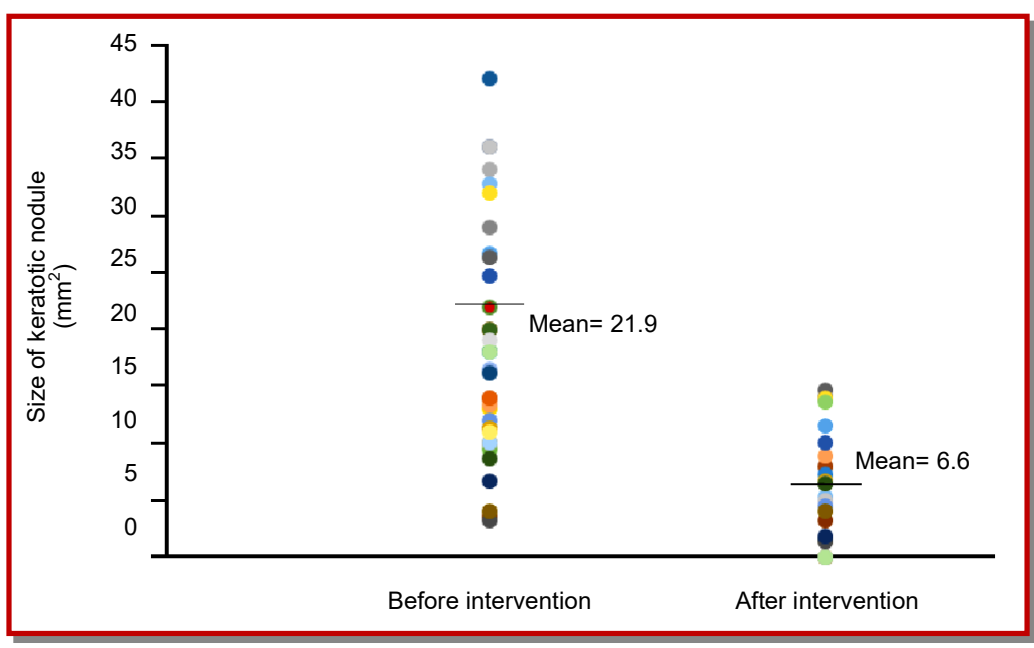

Figure 1: Diagram showing the reduction of keratotic nodules

tively. The mean duration of exposure to arsenic contaminated water of the patients was $9.3 \pm 2.0$ years. The mean duration of the appearance of keratosis was $4.6 \pm 2.1$ years

Seven patients were dropped out during the study period due to loss to follow-up.

\section{Size of the lesions}

The mean $( \pm \mathrm{SD})$ size of the keratotic nodules was $21.9 \pm 10.0 \mathrm{~mm}^{2}$ before intervention and the mean size was reduced to $6.6 \pm 5.3 \mathrm{~mm}^{2}$ after intervention (Figure 1). The percentage of reduction was 69.8. Statistical analysis was done by paired t-test and $\mathrm{p}$ value was 0.0001 . The result was statistically significant.

\section{Brine shrimp toxicity assay}

A concentration-dependent death of nauplii was observed after 24 hours in the brine shrimp

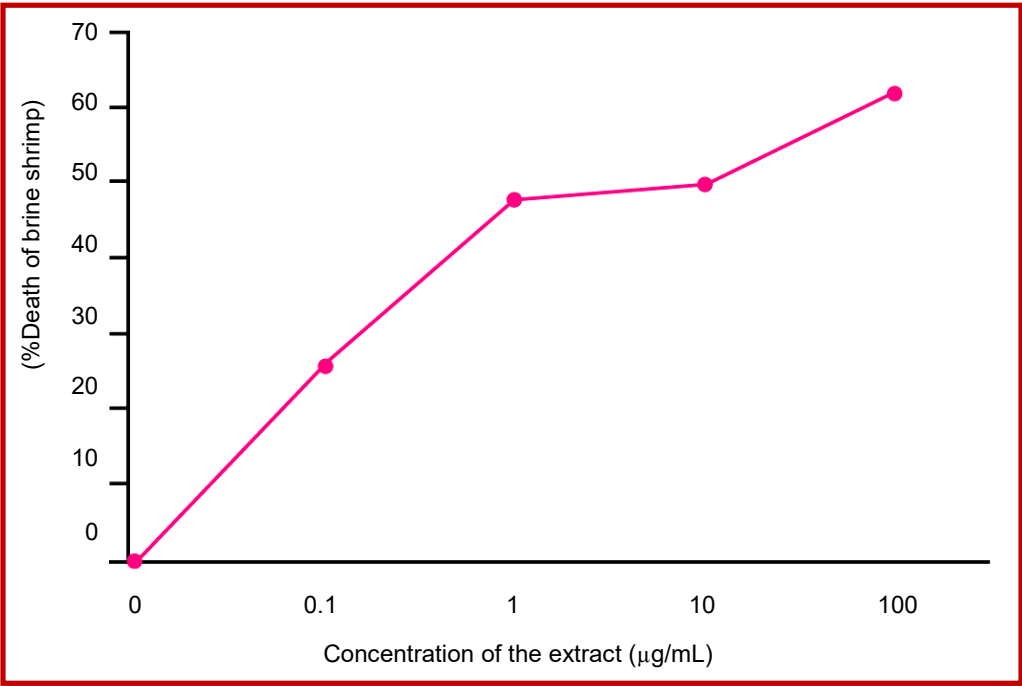

Figure 2: Diagram showing the cytotoxic effect of S. melongena peel extract on brine shrimp at different concentrations cytotoxicity test performed in artificial sea water. The net dead of nauplii was found $26,48,50$ and $62 \%$ at $0.1,1.0,10$ and $100 \mu \mathrm{g} / \mathrm{mL}$ concentrations of the extract respectively (Figure 2 ).

\section{Characteristics of the extract}

Total $510 \mathrm{~g}$ extract was obtained from $140 \mathrm{~kg}$ of $S$. melongena. The extract was dark brown in color, semisolid in consistency and pungent in odor. It was soluble in methanol, dichloromethane and chloroform but insoluble in butanol, n-hexane and acetone.

Yield: $0.4 \%$; dark brown semisolid; $\mathrm{R}_{\mathrm{f}}$ : 0.31 (dichloromethane: chloroform 1:1); IR (KBr) $\mathrm{n}_{\max }$ ( $\mathrm{cm}^{-1}$ ): 2954 (N-H amine salt), 2848 (C-H aliphatic), 1707 ( $\mathrm{C}=\mathrm{O}$ carboxylic acid), 1463 ( $\mathrm{C}-\mathrm{H}$ aliphatic), 1411 (O-H alcohol), 1226 (C-N amine), 1170 (C-O ester), 719 ( $\mathrm{C}=\mathrm{C}$ alkene) $\mathrm{cm}^{-1}$ (Table I; Supplementary file); ${ }^{1} \mathrm{H}-\mathrm{NMR}\left(\mathrm{CDCl}_{3}, 400 \mathrm{MHz}, 27^{\circ} \mathrm{C}\right.$, TMS $) \mathrm{d}$ (ppm): 0.879 (9H, m, J=5.1 Hz), $1.272(42 \mathrm{H}, \mathrm{d}, J=14.1$ $\mathrm{Hz}), 1.643(7 \mathrm{H}, \mathrm{q}, J=6 \mathrm{~Hz}), 2.787(1 \mathrm{H}, \mathrm{m}, J=5.7 \mathrm{~Hz})$, $3.896(2 \mathrm{H}, \mathrm{m}, J=6 \mathrm{~Hz}), 4.639(34 \mathrm{H}, \mathrm{s}), 5.377(2 \mathrm{H}, \mathrm{d}$, $J=1.5 \mathrm{~Hz}$ ) (Table II; Supplementary file); ${ }^{13} \mathrm{C}$ NMR: $\left(400 \mathrm{MHz}, \mathrm{CDCl}_{3}\right): 138.2,127.9,71.8,51.2,49.5,42.2$ 40.4, 37.3, 34.0, 32.6, 31.5, 29.6, 20.6, 18.9, 14.2; LCMS: 413.0 (Table III; Supplementary file); Analysis calculated for $\mathrm{C}_{27} \mathrm{H}_{43} \mathrm{NO}_{2}$ : C, 78.3; $\mathrm{H}, 10.3 ; \mathrm{N}, 3.3 ; \mathrm{O}$, 7.7; Found: C, 67.8; H, 11.9; N, 0.44 (Supplementary file).

\section{Discussion}

The patients with moderate to severe palmar arsenical keratosis were treated with the ointment containing $S$. melongena peel extract and it was found to be effective in the reduction of the size of the keratotic nodules. Nuclear magnetic resonance, infrared spectroscopy, elemental analysis and liquid chromatography-mass spectrometry of the extract were done and solasodine, a steroidal alkaloid, was identified.

This is the second study to evaluate the effects of $S$. melongena peel extract on arsenical keratosis. The first study was done at the same department where improvement of keratosis was found after application of extract containing ointment. $\frac{3}{\text { In }}$ the present study, improvement was also found after applying the ointment containing $S$. melongena peel extract. About $10 \%$ of the total patients mentioned about slight burning sensation during the time of ointment application and that was within their allowable limit.

The presence of solasodine in the S. melongena peel extract was based on data obtained from nuclear magnetic resonance, infrared spectra and liquid chromatography-mass spectrometry of the extract. Elemental analysis of the extract was also done but no conclusion could be reached due to failure to 


\begin{tabular}{|c|c|c|}
\hline \multicolumn{3}{|c|}{ Table I } \\
\hline \multicolumn{3}{|c|}{ Wave number of the FTIR bands } \\
\hline IR bands & $\begin{array}{l}\text { Wave number }\left(\mathrm{cm}^{-1}\right) \text { of the } \\
\text { extract (present study) }\end{array}$ & $\begin{array}{l}\text { Wave number }\left(\mathrm{cm}^{-1}\right) \text { of so- } \\
\text { lasodine (Bhattacharya et al., } \\
\text { 2013) }\end{array}$ \\
\hline $\mathrm{N}-\mathrm{H}$ & 2954.9 & 2950 \\
\hline $\mathrm{C}-\mathrm{H}$ & 2848.8 & 2880 \\
\hline $\mathrm{C}=\mathrm{O}$ & 1707.0 & 1733 \\
\hline $\mathrm{C}-\mathrm{H}$ & 1463.9 & 1693 \\
\hline $\mathrm{O}-\mathrm{H}$ & 1411.8 & \\
\hline $\mathrm{C}-\mathrm{N}$ & 1226.7 & \\
\hline $\mathrm{C}-\mathrm{O}$ & 1170.7 & \\
\hline $\mathrm{C}=\mathrm{C}$ & 719.4 & \\
\hline
\end{tabular}

Table II

${ }^{1} \mathrm{H}-\mathrm{NMR}$ chemical shifts ( $\delta$ in $\left.\mathrm{ppm}\right)$

\begin{tabular}{|c|c|c|c|}
\hline Proton No. & Present study & $\begin{array}{l}\text { Solasodine of } S \text {. } \\
\text { melongena peel origin } \\
\text { (Shabana et al., 2013) }\end{array}$ & $\begin{array}{l}\text { Solasodine of } S \text {. } \\
\text { platanifolium origin } \\
\text { (Puri et al., 1994) }\end{array}$ \\
\hline 1 & 1.6 & 1.7 & 1.8 \\
\hline 2 & 2.0 & 2.1 & 1.7 \\
\hline 3 & 3.8 & 3.8 & 3.4 \\
\hline 4 & 2.7 & 2.7 & 2.2 \\
\hline 6 & 5.3 & 5.3 & 5.3 \\
\hline 7 & 1.3 & 1.3 & 1.4 \\
\hline 8 & 1.6 & 1.5 & 1.5 \\
\hline 9 & 0.8 & 0.8 & 0.9 \\
\hline 11 & 1.3 & 1.4 & 1.4 \\
\hline 12 & 1.6 & 1.7 & 1.6 \\
\hline 14 & $1.2,2.0$ & $1.0,2.0$ & 1.0 \\
\hline 16 & 4.6 & 4.5 & 4.2 \\
\hline 17 & 1.6 & 1.8 & 1.6 \\
\hline 18 & 0.8 & 0.8 & 0.7 \\
\hline 19 & 1.2 & 1.0 & 0.9 \\
\hline 20 & 1.6 & 1.9 & 1.8 \\
\hline 23 & 1.6 & 1.7 & 1.5 \\
\hline 24 & 1.6 & 1.6 & 1.5 \\
\hline 25 & $1.3,2.7$ & $1.4,2.7$ & 1.4 \\
\hline 26 & 2.8 & 2.8 & 2.5 \\
\hline
\end{tabular}

obtain the percentage of oxygen.

S. melongena peels are reported to possess steroidal alkaloids: solasodine, solamargine and solasonine. 9 These compounds exhibited moderate to potent activities against carbon tetrachloride-induced hepatocellular carcinoma in rats. The killing effect of the cancer cells by solasodine glycoside may be due to a) lysis of the cells after expressing specific endogenous endocytic lectins. This component is more specific for the cancer cells than the normal cells and b) inducing apoptosis of the cells by upregulation of tumor necrosis factor and Fas receptor. 10

S. melongena peel also possess antioxidant activity as it contains anthocyanin; delphinidine-3-(p-cumaroylrutinoside)-5-glucoside that is nasunin.11-12 Delphinidine has an inhibitory effect on human fibrosarcoma HT-1080 invasiveness in vitro. $\underline{13}$

A study conducted to isolate solasodine from Solanum xanthocarpum where Fourier transform infrared spectra of solasodine were $\mathrm{n}_{\max }(3400,2950,2880$, 1733, $16930 \mathrm{~cm}^{-1}$ ) (Table I; Supplementary file). $\underline{.4} \mathrm{In}$ the present study, the Fourier transform infrared spectra $\left(\mathrm{cm}^{-1}\right)$ of $S$. melongena extract were at 2954.9 due to N-H stretching for amine salt, 2848.8 due to $\mathrm{C}-\mathrm{H}$ stretching for alkane, 1734.0 due to $\mathrm{C}=\mathrm{O}$ stretching for ester, 1707.0 due to $\mathrm{C}=\mathrm{O}$ stretching for carboxylic acid.

Spectra of ${ }^{1} \mathrm{H}$ nuclear magnetic resonance (Shabana et al., 2013) for solasodine were similar to that of the present study (Table II; Supplementary file). .9

Anti-cancer activity of the fruit peels of S. melongena was revealed in a study. - In that study, the ${ }^{13} \mathrm{C}$ NMR spectra for solasodine were observed at 37.4, 32.0, 71.0, 42.5, 141.5, 120.7, 32.0, 31.5, 50.4, 36.7, 20.9 $39.9,40.4,56.5,31.5,78.7,63.2,15.9,18.9,41.4,14.7$, $97.9,34.2,30.4,31.0,47.5$ and $18.9 \mathrm{ppm}$ for $\mathrm{C}-1$ to $\mathrm{C}-$ 27 respectively. In the present study, the ${ }^{13} \mathrm{C}$ NMR spectra of $S$. melongena peel extract were observed at $37.4,32.6,71.8,42.2$, 138.2, 127.9, 32.6, 31.5, 50.2, 36.6, 20.6, 39.7, 40.4, 51.2, 31.5, 77.3, 51.2, 14.2, 18.9 $40.4,14.2,77.3,34.0,29.6,31.5,49.5$ and $18.9 \mathrm{ppm}$ for C-1 to C-27 respectively (Table III; Supplementary file).

Molecular weight of solasodine is 413.6 Dalton and in liquid chromatography-mass spectrometry, mass of the extract was detected 413.0 Dalton (Supplementary file). This steps for identification of compound present in the extract revealed that solasodine may be the compound responsible for this effect.

Solanum melongena peel extract has been reported to be effective in the treatment of arsenic-induced Bowen's disease. $\underline{15}$

\section{Conclusion}

This study suggests that ointment containing $S$. melongena peel extract is effective in reducing the size of the arsenical keratotic nodules. The preliminary steps for identification of compound present in the extract revealed that solasodine may be the compound responsible for this effect. 


\begin{tabular}{|c|c|c|c|c|}
\hline \multicolumn{5}{|c|}{ Table III } \\
\hline \multicolumn{5}{|c|}{${ }^{13} \mathrm{C}$-NMR chemical shifts ( $\delta$ in ppm) } \\
\hline $\begin{array}{c}\text { Carbon } \\
\text { No. }\end{array}$ & $\begin{array}{c}\text { Present } \\
\text { study }\end{array}$ & $\begin{array}{c}\text { Solasodine of } S \text {. } \\
\text { melongena peel } \\
\text { origin (Shabana } \\
\text { et al., 2013) }\end{array}$ & $\begin{array}{l}\text { Solasodine of } S . \\
\text { platanifolium } \\
\text { origin (Puri et } \\
\text { al., 1994) }\end{array}$ & $\begin{array}{c}\text { Solasodine of } S . \\
\text { laciniatum } \\
\text { origin } \\
\text { (Neszmelyi et } \\
\text { al., 1988) }\end{array}$ \\
\hline 1 & 37.4 & 37.4 & 37.1 & 37.4 \\
\hline 2 & 32.6 & 32.0 & 31.9 & 32.0 \\
\hline 3 & 71.8 & 71.0 & 71.6 & 71.0 \\
\hline 4 & 42.2 & 42.5 & 42.2 & 42.5 \\
\hline 5 & 138.2 & 141.5 & 140.9 & 141.5 \\
\hline 6 & 127.9 & 120.7 & 121.4 & 120.7 \\
\hline 7 & 32.6 & 32.0 & 32.0 & 32.0 \\
\hline 8 & 31.5 & 31.5 & 31.5 & 31.5 \\
\hline 9 & 50.2 & 50.4 & 50.0 & 50.4 \\
\hline 10 & 36.6 & 36.7 & 36.5 & 36.7 \\
\hline 11 & 20.6 & 20.9 & 20.7 & 20.9 \\
\hline 12 & 39.7 & 39.9 & 39.8 & 39.9 \\
\hline 13 & 40.4 & 40.4 & 40.4 & 40.4 \\
\hline 14 & 51.2 & 56.5 & 56.4 & 56.5 \\
\hline 15 & 31.5 & 31.6 & 32.0 & 31.6 \\
\hline 16 & 77.3 & 78.7 & 78.9 & 78.7 \\
\hline 17 & 51.2 & 63.2 & 62.7 & 63.2 \\
\hline 18 & 14.2 & 15.9 & 16.2 & 15.9 \\
\hline 19 & 18.9 & 18.9 & 19.3 & 18.9 \\
\hline 20 & 40.4 & 41.4 & 41.2 & 41.4 \\
\hline 21 & 14.2 & 14.7 & 15.1 & 14.7 \\
\hline 22 & 77.3 & 97.9 & 98.2 & 97.9 \\
\hline 23 & 34.0 & 34.2 & 33.9 & 34.2 \\
\hline 24 & 29.6 & 30.4 & 30.1 & 30.4 \\
\hline 25 & 31.5 & 31.0 & 31.3 & 31.0 \\
\hline 26 & 49.5 & 47.5 & 47.5 & 47.5 \\
\hline 27 & 18.9 & 18.9 & 19.1 & 18.9 \\
\hline
\end{tabular}

\section{Financial Support}

Bangabandhu Sheikh Mujib Medical University Research Grant (BSMMU/2018/931265)

\section{Ethical Issue}

The protocol was approved by the Institutional Review Board of Bangabandhu Sheikh Mujib Medical University (Reg. No. BSMMU/2018/2961).

\section{Conflict of Interest}

The authors have declared no conflict of interest.

\section{Acknowledgement}

We acknowledge the patients of two arsenic affected endemic areas for their co-operation during the study.

\section{References}

1. Hassan MM, Atkins PJ, Dunn CE. Social implications of arsenic poisoning in Bangladesh. Soc Sci Med. 2005; 61: 2201-11.

2. Alam MG, Allinson G, Stagnitti F, Tanaka A, Westbrooke M. Arsenic contamination in Bangladesh groundwater: A major environmental and social disaster. Int J Environ Health Res. 2002; 12: 235-53.

3. Sarah QS, Misbahuddin M. Effect of Solanum melongena peel extract in the treatment of arsenical keratosis. Bangabandhu Sheikh Mujib Med Univ J. 2019; 12: 80-83.

4. Caussy D. A field guide for detection, management and surveillance of arsenicosis cases. The World Health Organization, New Delhi, Regional Office for South East Asia, 2005, pp 6-7.

5. Bhuiyan HA, Tshering K, Misbahuddin M. Estimation of arsenic in nail using silver diethyldithiocarbamate method. Bangladesh J Pharmacol. 2015; 10: 513-17.

6. Sarah QS, Anny FC, Misbahuddin M. Brine shrimp lethality assay. Bangladesh J Pharmacol. 2017; 12: 186-89.

7. Meyer BN, Ferrigni NR, Putnam JE, Jacobsen LB, Nichols DJ, McLaughlin JL. Brine shrimp: A convenient general bioassay for active plant constituents. Planta Med. 1982; 45: 31-34.

8. Block LH. Ointment. In Remington: The science and practice of pharmacy. Genaro AR. (ed). $20^{\text {th }}$ ed. 2000, pp 845-46.

9. Shabana MM, Salama MM, Ezzat SM, Ismail LR. In vitro and in vivo anti-cancer activity of the fruit peels of Solanum melongena L. against hepatocellular carcinoma. J Carcinog Mutagen. 2013; 4: 149-54.

10. Cham BE, Daunter B, Evans RA. Topical treatment of malignant and premalignant skin lesions by very low concentrations of a standard mixture (BEC) of solasodine glycosides. Cancer Lett. 1991; 59: 183-92.

11. Igarashi K, Yoshida T, Suzuki E. Antioxidative activity of nasunin in chouja-nasu (little eggplant, Solanum melongena L. 'chouja'). Nippon Shokuhin Kogyo Gakkaishi. 1993; 40: 138-43.

12. Noda Y, Kneyuki T, Igarashi K, Mori A, Packer L. Antioxidant activity of nasunin, an anthocyanin in eggplant peels. Toxicology 2000; 148: 119-23.

13. Nagase H, Sasaki K, Kito H, Haga A, Sato T. Inhibitory effect of delphinidin from Solanum melongena on human fibrosarcoma HT-1080 invasiveness in vitro. Planta Med. 1998; 64: 216-19. 
14. Bhattacharya S, Kohli S, Chaudhary AS. Isolation of solasodine from the unripe fruits of Solanum xanthocarpum Schrad and Wendl. Solanaceae) and it's anti-cancer activity against HeLa and U937 cell lines. Austral-Asian J Cancer. 2013; 12: 199-213.
15. Sarah QS, Misbahuddin M. Effect of Solanum melongena peel extract in the treatment of arsenicinduced Bowen's disease. Bangladesh J Pharmacol. 2018; 13: 309-15. 